\title{
Absorption of Sulfur Dioxide in Water with High Salinity
}

\author{
IRINA PINCOVSCHI ${ }^{1}$, CRISTINA MODROGAN* \\ 'University Politehnica of Bucharest, Faculty of Hydraulic Machinery and Environmental Engineering, Department of Hydraulics, \\ 1-7 Polizu Str., 011061, Bucharest, Romania \\ ${ }^{2}$ University Politehnica of Bucharest, Faculty of Applied Chemistry and Materials Science, Department Analytical Chemistry and \\ Environmental Engineering, 1-7 Polizu Str., 011061, Bucharest, Romania
}

\begin{abstract}
Understanding the absorption behaviour of sulphur dioxide in aqueous electrolyte solutions is of major interest for the design of flue gas desulphurization processes, as for example wet flue gas desulphurization of coal fired power plants or municipal solid waste incineration plants. In the present paper the influence of the water salinity on $\mathrm{SO}_{2}$ absorption is studied. The $\mathrm{SO}_{2}$ absortion was performed in equilibrium condition. The variation of marine solubility from $10 \mathrm{~g} / \mathrm{L}$ to $40 \mathrm{~g} / \mathrm{L}$ determines the variation of $\mathrm{SO}_{2}$ concentration in water from $2.6 \mathrm{~mol} / \mathrm{L}$ to about $3.2 \mathrm{~mol} / \mathrm{L}$. In consequence, the variation of water salinity in these limits can detemine a quite big difference of water pollution.
\end{abstract}

Keywords: $\mathrm{SO}_{2}$, salinity, desulphurization processes

The importance of studied problem consists in the fact that the majority of planet water is of high salinity varying between $12 \mathrm{~g} / \mathrm{L}$ (Black Sea) and $35 \mathrm{~g} / \mathrm{L}$ (Atlantic Ocean). It results that the pollution of such waters with $\mathrm{SO}_{2}$ is quite different, varying in large limits [1].

Sulfur dioxide is removed from flue gas by absorption processes because of its toxicity. In fossil-fired power plants at the coast, alkaline seawater is often used as a scrubber agent to chemisorb the acid $\mathrm{SO}_{2}$. In arid regions frequently energy-intensive seaw ater desalination plants which produce fresh water and brine as a waste product are connected with the power plants. The brine is able to substitute seawater in flue gas desulfurization. However, for the design of such a process, systematic investigations of the influence of ions in the brine on $\mathrm{SO}_{2}$ absorption are lacking. Hence, a reliable process modeling and prediction of the brine's absorption capacity are not possible. Several working groups have modeled the solubility of $\mathrm{SO}$ in sea water on the basis of available models. Abdulsattar [3] has modeled the $\mathrm{SO}_{2}$ solubility in seawater in a temperature range from 10 to $25^{\circ} \mathrm{C}$. The activity coefficients of the ions were calculated from the Bromley model using an extended Debye-Hückel term [4], and the activity coefficients of the molecularly dissolved components were determined on basis of the coefficients of Rabe and Harris [5] as well as Garrels and Christ [6]. Al-Enezi [7] investigated the solubility of $\mathrm{SO}_{2}$ in sea water solutions at salinities from 0 to $65 \mathrm{~g} / \mathrm{kg}$, temperatures between $10^{\circ} \mathrm{C}$ and $40^{\circ} \mathrm{C}$ and constant $\mathrm{SO}_{2}$ partial pressure of $22.4 \mathrm{~Pa}$. The applied model is based on the approach of Abdulsattar [3] and includes an extended Debye-Huckel term to describe the activity coefficients. As a result, a quadratic equation of the $\mathrm{SO}_{2}$ solubility was fitted as a function of temperature and salinity. However, the equation allows no extrapolations to other $\mathrm{SO}_{2}$ partial pressures and is therefore limited in their applicability [8-17].

Sulfur dioxide affects the environment in different ways, like direct absorption in water, acid rains and health damages [2, 18-19]. The concentration of SO in residual gases emitted by thermal power plants is about $0.15-0.25 \%$. The $\mathrm{SO}_{2}$ concentration can to attain bigger values, like in metalurgical ones (1-2 \%).

In contrast to the work cited above, in this work the absorption of $\mathrm{SO}_{2}$ in fundamental binary systems (water +1 salt) present in seawater was experimentally investigated and modeled first to determine reliable model parameters for the main components of the electrolyte systems seawater.

\section{Theoretical approach}

The $\mathrm{SO}_{2}$ absorption in water is a phisicochemical process developped as follows:

$$
\begin{aligned}
& \mathrm{SO}_{2}+\mathrm{H}_{2} \mathrm{O} \stackrel{\mathrm{K}_{1}}{\longleftrightarrow} \mathrm{H}_{2} \mathrm{SO}_{3} \stackrel{\mathrm{K}_{2}}{\longleftrightarrow} \mathrm{H}^{+}+
\end{aligned}
$$

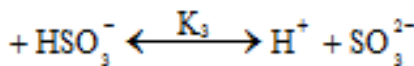

In the equation (1) the proton $\mathrm{H}^{+}$represents the strongly hidrated ion $\mathrm{H}_{2} \mathrm{O}^{+}$.

$\mathrm{K}_{1}, \mathrm{~K}_{2}$ and $\mathrm{K}_{3}$ representing the equilibrium constants:

$$
\begin{aligned}
\mathrm{K}_{1} & =\frac{\left[\mathrm{H}_{2} \mathrm{SO}_{3}\right]}{\left[\mathrm{SO}_{2}\right] \cdot\left[\mathrm{H}_{2} \mathrm{O}\right]} \\
\mathrm{K}_{2} & =\frac{\left[\mathrm{H}^{+}\right] \cdot\left[\mathrm{HSO}_{3}^{-}\right]}{\left[\mathrm{H}_{2} \mathrm{SO}_{3}\right]} \\
\mathrm{K}_{3} & =\frac{\left[\mathrm{H}^{+}\right] \cdot\left[\mathrm{SO}_{3}^{2-}\right]}{\left[\mathrm{HSO}_{3}^{-}\right]}
\end{aligned}
$$

where: $\left[\mathrm{SO}_{2}\right]$ is the physically absorbed sulfur dioxide concentration;

$\left[\mathrm{H}_{2} \mathrm{SO}_{3}\right]$ - the chemically absorbed sulfur dioxide concentration;

$\left[\mathrm{HSO}_{3}^{-}\right]$- concentration of ions resulting from the first step of $\mathrm{H}_{2} \mathrm{SO}_{3}$ dissociation;

$\left[\mathrm{SO}_{3}{ }_{3}^{2}\right]^{2}$ - concentration of ions resulting from the second step of $\mathrm{H}_{2} \mathrm{SO}_{3}$ dissociation;

$\left[\mathrm{H}^{+}\right]$- hydrogen ion concentration;

$\left[\mathrm{H}_{2} \mathrm{O}\right]$ - water concentration.

The equilibrium of $\mathrm{SO}_{2}-\mathrm{H}_{2} \mathrm{O}$ system may be appreciated using the equation [12]:

$$
\mathrm{p}_{\mathrm{SO}_{2(\mathrm{e})}}=\mathrm{H}\left\{\left[\mathrm{SO}_{2}\right] \cdot\left[\mathrm{H}_{2} \mathrm{SO}_{3}\right]\right\}
$$


where: $p_{\text {s02 (e) }}$ represents the equilibrium pressure of sulfur dioxide,

$\mathrm{H}$ - Henry constant. form:

The equation (5) can be transformed in a more explicit

$$
\mathrm{p}_{\mathrm{SO}_{2(0)}}=\mathrm{HS} \cdot \frac{1+\mathrm{K}_{1}}{\mathrm{~K}_{1}} \cdot \frac{\left[\mathrm{H}^{+}\right]^{2}}{\left[\mathrm{H}^{+}\right]^{2}+\mathrm{K}_{2} \cdot\left[\mathrm{H}^{+}\right]+\mathrm{K}_{2} \cdot \mathrm{K}_{3}}
$$

where S represents the sum of chemisorbed species:

$$
\mathrm{S}=\left[\mathrm{H}_{2} \mathrm{SO}_{3}\right]+\left[\mathrm{HSO}_{3}^{-}\right]+\left[\mathrm{SO}_{3}^{2-}\right]
$$

and

$\mathrm{K}_{1}^{\prime}$ is the ratio between chemically and physically absorbed species:

$$
\mathrm{K}_{1}=\mathrm{K}_{1} \cdot\left[\mathrm{H}_{2} \mathrm{O}\right]=\frac{\left[\mathrm{H}_{2} \mathrm{SO}_{3}\right]}{\left[\mathrm{SO}_{2}\right]}
$$

Equation (2) highlights the equilibrium concentration of physically absorbed sulfur dioxide:

$$
\left[\mathrm{SO}_{2}\right]=\frac{\left[\mathrm{H}_{2} \mathrm{SO}_{3}\right]}{\mathrm{K}_{1}\left[\mathrm{H}_{2} \mathrm{O}\right]}=\frac{\left[\mathrm{H}_{2} \mathrm{SO}_{3}\right]}{\mathrm{K}_{1}}
$$

Combining equations (5) and (9) one obtain:

$$
\mathrm{p}_{\mathrm{SO}_{2}}=\mathrm{H}\left\{\frac{\left[\mathrm{H}_{2} \mathrm{SO}_{3}\right]}{\mathrm{K}_{1}}+\left[\mathrm{H}_{2} \mathrm{SO}_{3}\right]\right\}=\mathrm{H}\left\{\left[\mathrm{H}_{2} \mathrm{SO}_{3}\right] \cdot \frac{1+\mathrm{K}_{1}}{\mathrm{~K}_{1}}\right\}
$$

The concentration of chemisorbed species $\left[\mathrm{H}_{2} \mathrm{SO}_{3}\right]$ can be expressed, combining the relations (3), (4) and (7):

$$
\left[\mathrm{H}_{2} \mathrm{SO}_{3}\right]=\mathrm{S} \cdot \frac{\left[\mathrm{H}^{+}\right]}{\left[\mathrm{H}^{+}\right]^{2}+\mathrm{K}_{2}\left[\mathrm{H}^{+}\right]+\mathrm{K}_{2} \cdot \mathrm{K}_{3}}
$$

By substituting the equation (11) in (10) we obtain the equation (6). The equilibrium constants $K_{2}=1.7 \times 10^{-2}$ and $\mathrm{K}_{3}=6.2 \times 10^{-8}$ from equation (6) have the significance of ionization constants, indicating the $\mathrm{H}_{2} \mathrm{SO}_{3}$ strength [11]. The low values of ionization constants $\mathrm{K}_{2}$ and $\mathrm{K}$ are indicating the weak character of sulfurous acid $\left(\mathrm{H}_{2} \mathrm{SO}_{3}\right)$. Both constants can be used in calculating the proton concentration after the first and the second ionization step, according to equations:

$$
\begin{aligned}
& {\left[\mathrm{H}^{+}\right]_{1}=\sqrt{\mathrm{K}_{2}[\mathrm{C}]}} \\
& {\left[\mathrm{H}^{+}\right]_{2}=\sqrt{\mathrm{K}_{3}[\mathrm{C}]}}
\end{aligned}
$$

where: $\left[\mathrm{H}^{+}\right]_{1}$ represents the proton concentration after the first step of ionization;

$\left[\mathrm{H}^{+}\right]_{2}$ - the proton concentration after the second step of ionization;

[C] - the total sulfur dioxide concentration in water.

Considering the equation (6) one can see the correlation between $\mathrm{SO}_{2}$ equilibrium pressure, the solution $\mathrm{pH}$ and temperature ( $\mathrm{K}_{2}$ and $\mathrm{K}_{3}$ are functions of temperature). This dependence can be put in evidence experimentally.

\section{Experimental part}

The absorbtion of $\mathrm{SO}_{2}$ in water was experimented in a device presented in figure 1 [16]. It contains a $\mathrm{SO}_{2}$ measurement vessel (1) having the volume $V$, an absorption vessel (2) whose volume is $v$, a mercury manometer (3) and a water manometer (4). The mercury manometer is used for high $\mathrm{SO}_{2}$ concentrations and the water manometer for low $\mathrm{SO}_{2}$ concentrations. The order of operations is the following: by slowly opening the tap (8) a vacuum $\left(\Delta h_{1}\right)$ is made in the vessel (1). Then closing

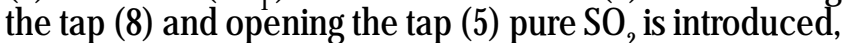
establishing the initial pressure. Closing the tap (5) and opening the tap (9) the communication between the vessel (1) and (2) is established, permitting the $\mathrm{SO}_{2}$ absorption in the absorbent contained in the vessel (2) till the equilibrium is attained. The $\mathrm{SO}_{2}$ absorption determines the creation of a vacuum $\left(\Delta h_{2}\right)$. Knowing $\Delta h_{1}$ and $\Delta h_{2}$ values and the amount of absorbent $(\mathrm{g})$, a point on equilibrium diagram can be represented.

Let's consider the following example. The volume $V=$ $370 \mathrm{~cm}^{3}, v=30 \mathrm{~cm}^{3}, \Delta \mathrm{h}_{1}=300 \mathrm{~mm} \mathrm{Hg} \Delta \mathrm{h}_{2}=53 \mathrm{~mm} \mathrm{Hg}$.

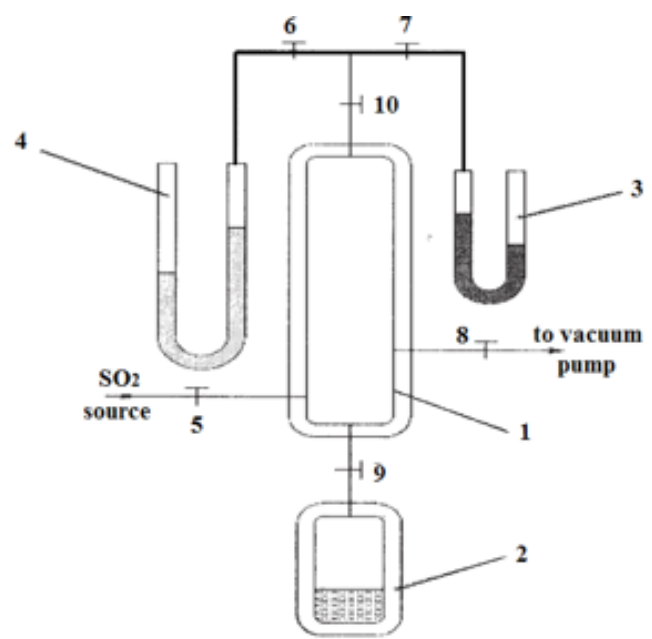

Fig. 1. Experimental device for water- $\mathrm{SO}_{2}$ equilibrium study 1 thermostated vessel; 2 -thermostated absorption vessel; 3 mercury manometer; 4 -water manometer; 5, 6, 7, 8, 9, 10 -taps [16]

In these conditions the $\mathrm{SO}_{2}$ volume $\mathrm{V}_{\mathrm{T}}$ introduced in the vessel (1) is:

$$
\mathrm{V}_{\mathrm{T}}=\mathrm{V} \cdot \frac{\Delta \mathrm{h}_{1}}{\mathrm{P}_{\mathrm{T}}}=370 \cdot \frac{300}{760}=146 \mathrm{~cm}^{3}
$$

where $\mathrm{P}_{\mathrm{T}}$ is the total pressure (for example the atmospheric one).

The absorbed $\mathrm{SO}_{2}$ volume is $\mathrm{v}_{\mathrm{abs}}$

$$
\mathrm{v}_{\mathrm{abs}}=(\mathrm{v}+\mathrm{v}) \cdot \frac{\Delta \mathrm{h}_{2}}{\mathrm{P}_{\mathrm{T}}}=(370+30) \cdot \frac{53}{760}=27.9 \mathrm{~cm}^{3}
$$

The non-absorbed $\mathrm{SO}_{2}$ volume $v_{r}$ is

$$
\mathrm{v}_{\mathrm{r}}=\mathrm{V}_{\mathrm{T}}-\mathrm{v}_{\mathrm{abs}}=146-27.9=118.1 \mathrm{~cm}^{3}
$$

The equilibrium $\mathrm{SO}_{2}$ pressure $\Delta \mathrm{h}_{\mathrm{e}}$ is: 


$$
\begin{aligned}
& \Delta \mathrm{h}_{\mathrm{e}}=\mathrm{p}_{\mathrm{e}}=\Delta \mathrm{h}_{1} \cdot \frac{\mathrm{V}}{\mathrm{V}+\mathrm{v}}-\Delta \mathrm{h}_{2}= \\
& =300 \cdot \frac{370}{370+30}-53=225 \mathrm{~mm} \mathrm{Hg}
\end{aligned}
$$

Knowing the amount of absorbent $\mathrm{g}=3 \mathrm{~g} \mathrm{H}_{2} \mathrm{O}$, the $\mathrm{SO}$ concentration $\mathrm{C}_{\mathrm{SO}_{2}}$ can be calculated (in $\mathrm{g} \mathrm{SO}_{2} / \mathrm{IOOO}^{2} \mathrm{H}_{2} \mathrm{O}$ ) as follows:

$$
\begin{aligned}
C_{\mathrm{SO}_{2}}= & \frac{27.9\left[\mathrm{~cm}^{3}\right]}{22400\left[\mathrm{~cm}^{3} / \mathrm{mol}\right]} \cdot 64\left[\frac{\mathrm{gSO}_{2}}{\mathrm{~mol}}\right] \cdot \frac{1000}{3}= \\
& =26.5\left[\mathrm{~g} \mathrm{SO}_{2} / 1000 \mathrm{~g} \mathrm{H}_{2} \mathrm{O}\right]
\end{aligned}
$$

\section{Results and discussions}

The experimental method permits to determine the following equluilibrium curves:

1)The dependence of sulfur dioxid concentration in liquide phase, $\mathrm{C}_{\mathrm{SO} 2}[\mathrm{~mol} / \mathrm{L}]$ on sulfur dioxid partial pressure, $\mathrm{p}_{\mathrm{SO}}[\mathrm{mm} \mathrm{Hg}]$ at different water salinity $\mathrm{S}[\mathrm{g} / \mathrm{L}]$ (fig. 2) and

2)The dependence of sulfur dioxid concentration in liquide phase $\mathrm{C}_{\mathrm{SO}_{2}}[\mathrm{~mol} / \mathrm{L}]$ on water salinity $\mathrm{S}[\mathrm{g} / \mathrm{L}]$. (fig. 3 )

From the figure 2 one can see that the $\mathrm{SO}_{2}$ cnceentration in liquide phase is decreasing when the salinity $S$ is increasing. This dependence results also from the figure 2. The knowing of these dependences permits to establish tha $\mathrm{SO}_{2}$ pollution in different conditions.

The results obtained are presented in figure 3 as a equilibrium diagramme between the solubility of water $S$ $[\mathrm{g} / \mathrm{L}]$ and $\mathrm{SO}_{2}$ concentration $\mathrm{C}_{\mathrm{SO}_{2}}[\mathrm{~mol} / \mathrm{L}]$. The variation of marine solubility from $10 \mathrm{~g} / \mathrm{L}$ to $40 \mathrm{~g} / \mathrm{L}$ determines the

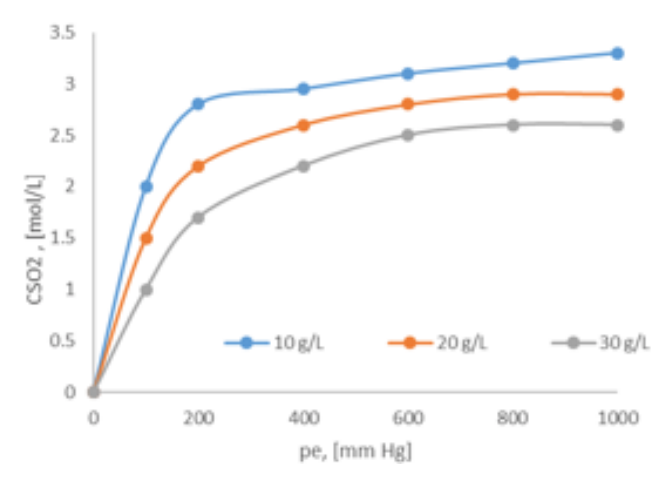

Fig. 2. The dependence of $\mathrm{SO}_{2}$ concentration in liquide phase, $\mathrm{C}_{\mathrm{SO2}}[\mathrm{mol} / \mathrm{L}]$ on $\mathrm{SO}_{2}$ partial presure $\mathrm{p}_{\mathrm{SO2}}[\mathrm{mm} \mathrm{Hg}]$ at different

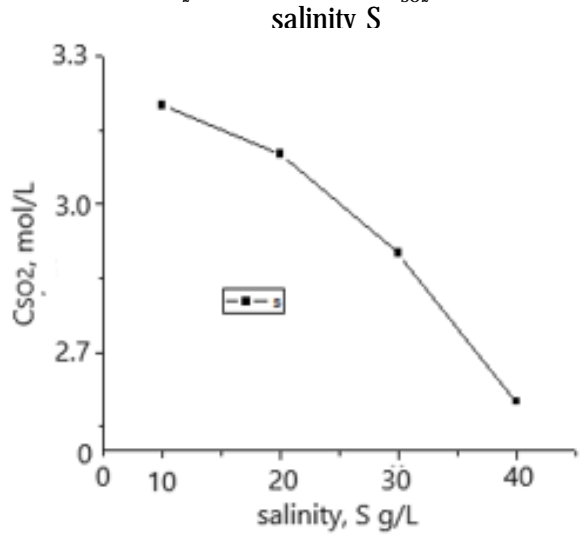

Fig. 3. The dependence of $\mathrm{SO}_{2}$ concnetration in liquide phase, $\mathrm{C}_{\mathrm{SO2}},[\mathrm{mol} / \mathrm{L}]$ on water salinity, $\mathrm{S}[\mathrm{g} / \mathrm{L}]$ variation of $\mathrm{SO}_{2}$ concentration in water from $2.6 \mathrm{~mol} / \mathrm{L}$ to about $3.2 \mathrm{~mol} / \mathrm{L}$. In consequence, the variation of water salinity in these limits can detemine a quite big difference of water pollution.

\section{Conclusions}

The study reveals a big influence of salinity of water on $\mathrm{SO}$ concentration in water, showing that even atbig salinity $(40 \mathrm{~g} / \mathrm{L})$ the concentration is big enough to create the conditions for natural waters acidification. The $\mathrm{SO}_{2}$ concentration determined by $\mathrm{SO}_{2}$ absorption from polluting gases can attain $26.5 \mathrm{~g} / 1000 \mathrm{~g}$ water. This concentration is quite low for water acidification because of weak character of $\mathrm{H}_{2} \mathrm{SO}_{3}$ resulting from $\mathrm{SO}_{2}$ absorption. Unfortunately in natural waters there are favorable conditions for $\mathrm{SO}_{2}$ oxidation, conducting finally to $\mathrm{H}_{2} \mathrm{SO}_{4}$ formation. Only $0.5 \mathrm{H}_{2} \mathrm{SO}_{4} \mathrm{~g} / 1000 \mathrm{~g} \mathrm{H}_{2} \mathrm{O}$ can determine the value of water $\mathrm{pH}$ about 3 , damaging the fauna and flora. In order to put in evidence the influence of $\mathrm{SO}_{2}$ partial pressure and temperature on $\mathrm{SO}_{2}$ concentration in water, equilibrium diagrams have been determined. These diagrams can be also used to design $\mathrm{SO}_{2}$ absorption devices.

Acknowledgment: This work has been funded by University Politehnica of Bucharest, through the Excellence Research Grants"Program, UPB -GEX 2017. Identifier: UPB- GEX2017, Ctr. No. 78/2017Cod 136.

\section{References}

1.DONABUL, A., RILEY, J., J. Chem. Engng. Data, 2a, 1979, 276

2.ORBULET, O.D., PINCOVSCHI, I., MODROGAN, C., Rev. Chim. (Bucharest), 67, no. 5, 2016, p. 829

3.ABDULSATTAR, A.H., SRIDHAR, S., BROMLEY, L.A., AIChE J. (January), 1977, p. 62

4.BROMLEY, L., J. Chem. Thermodyn. 4, 5, 1972, p. 669

5.RABE, A.E., HARRIS, J.F., J. Chem. Eng. Data, 8, 3, 1963, p. 333

6.GARRELS, M.R., CHRIST, C.L., Harper and Row, New York, 1965, p. 450.

7.ANDREASE, A., Mayer, S., 2007, ACS Publication

8.OSLO, A.E., LILLESTRIM,T.A., United State Patent, 4,337,230, 1982 9.OIKAWA, K., YONGSIRI, C., HARIMOTO, T., Environmental Progress AICHE \&Sustainable Energy, 22, 1, 2003, p. 67

10.RODRIGUEZ-SEVILLA, J., ALVAREZ, M., DIAZ, M.C., MARRERO, M.C., J. Chem. Eng. Data, 49, 6, 2004, p. 1710

11.MEINRAT, O.A., Marine Chemistry, 30, 1990, p. 1

12.KUMAR, S.P., J. of Geophysical Reserch, 104, C1, 1999, p. 1455

13.EDUARDO, T., MIYAUCHI, C., LU, Y., FIROOZABADI, A., Society of Petroleum Engineers, SPE-187275-MS, 2017, https://doi.org/10.2118/ 187275-MS

14.YU, L., JIN, X., JOSEY, S.A., LEE, T., KUMAR, A., WEN, C., XUE, Y., J. of Climate, 30, 2017, p. 3829

15.HARRIS, C., MCCLELLAND, W., CONNELLY, T.L., CRUMP, B.C., DUNTON, K.H., Estuarin and Coasts, 40, 1, 2017, p. 50

16.PINCOVSCHI, I., STEFAN, S.D., Rev. Chim (Bucharest), 64 , no. 9, 2013, p. 1021

17.DRAGAN, G., Rev. Chim (Bucharest), 61, no. 9, 2010, p. 897

18.AXENTE, D., BALLA, A., MARCU, C., Rev. Chim (Bucharest), 67, no. 8, 2016, p.1551

19.STANCU, A., CALIN, C., PANTEA O., ENE, C., Rev. Chim (Bucharest), 66,no. 6, 2015, p. 778

Manuscript received: 14.06 .2018 